\title{
Meursault as a Christ Figure in Camus's The Outsider
}

\author{
Dr. Shraddha Dhal \\ Faculty Associate, School of Humanities, KIIT Deemed to be University, Bhubaneswar, India
}

\begin{abstract}
Jesus Christ is not a divine being, but a human form that attains divinity by love, compassion, honesty and truthfulness. Christ's admiration for the infinite value of truth, honesty and integrity essentially makes him saintly. However, his human frailty drifts in the periphery of his godliness. Camus brings forth Meursault, his lead character in The Outsider as an apparently 'Christ-like figure', whose commitment to truth and honesty sanctifies his soul and puts a voice to it that alleviates his fear of death. His peculiarity and honesty ostensibly form a duality in his character like Christ, whose human-like and divine-like traits co-exist in him concomitantly. An honest man reiterates the same assertion while a dishonest man tries to manipulate his words and may give surprising directions to the same every time he is confronted. Honesty is telling the truth while integrity is living what is told. Meursault is honest to the extent that he, like Christ, does not learn to fake when he is castigated or even guillotined. His veracity and his mighty wave of passionate commitment to truth extinguish him from the feigned psyche of his immediate society- truth loved-told-lived. His spontaneity is his honesty and this honesty makes him vulnerable. The present paper is a fine illustration of Camus's endorsement of Meursault as a 'Christ-figure' with correspondence to his (Meursault's) purpose, his persona and his providence to that of Christ.
\end{abstract}

Keywords: convention; honesty; integrity; society; truth.

\section{Introduction}

Jesus Christ is a multi-faceted personality. He is noble, generous; at the same time, he is a man with typical human frailty. He is not a divine creature; he is one who achieves divinity. Nevertheless, he sets an incredible example of sacrifice and dedication to truth and justice. Christ loves truth because he knows truth can change anything, but lie destroys everything. He loves truth because he knows that only truth sets people free, brings growth and lifeabundant and overflowing. His commitment to truth renewed our hunger for truth- truth lived, truth felt and truth embraced. However, truth by definition is exclusive and narrow. Lie, on the other hand, is not only limited to what is not true, but also understood as saying more than what is actually felt. Lie simplifies life; truth complicates many things. Christ does not care about simplifying life by disguising his feelings. He denies unique and exclusive approach to truth. He would insist that his own approach is unique and exclusive. He has the integrity, deep honesty and a passionate commitment to truth. He was martyred because his society considered him a dangerous character, but he is honest, too honest that he accepts to die for truth. His fearless love for truth and his selfless love for humanity make him a simple man with extraordinary power. 


\section{Discussion}

Arthur Meursault, the protagonist of the novel, The Outsider has several traits which are unacceptable to his immediate society. The only redeeming quality that makes him uniquely individual is his idiosyncratic honesty, no matter how absurd it appears to be. In existential terms, he is authentic to himself. Unlike most, Meursault does not think it is crucial to fake through just to facilitate people feel as pleased as punch. He is genuine, true to life that goes beyond anybody's feeling of being understood, of being given importance. He just acts in accordance with his veracious self. Meursault distrusts the sentimental language that society invents. He is the freest of men that is, liberated from moral ideologies. In his way he is as happy as it is possible to be. He is authentic not artificial. In this sense, he is a stranger to the society he lives in, because he refuses to lie, to pretend. Far from being bereft of all sensitivity, a deep passion animates him, a passion for the absolute and for truth. Far from being bereft of all sensitivity, a deep passion animates him, a passion for the absolute and for truth. This inability to falsify empathy eventually gets him into trouble and his brutal honesty finally condemns him to death.

Camus proclaims, "Meursault, for me, is a poor and naked man in love with the sun which leaves no shadows. He is far from being totally deprived of sensitivity for he is animated by a passion, profound because it is tacit, the passion for the absolute and for truth. It is still a negative truth of being and feeling, but a truth without which no conquest of the self or of the world is possible."..."Meursault is the man who answers but never asks a question, and all his answers so alarm a society which cannot bear to look at the truth." (p. 38) Camus, with these words effectively justifies his protagonist's radical honesty and candor. Towards the end of the novel, the author draws our attention to equate this peculiar character with the figure of the crucified Christ. Meursault, unlike the mass, is an uncharacteristic being, who is indifferent to the social conventions, derives satisfaction from hedonistic doings, does not demonstrate fake emotions, and remains true to his self.

This is evident when Meursault learns that his mother is dead and he has to go with the funeral proceedings, he doesn't react emotionally. He tells of his mother's funeral objectively, but unfeelingly; it exhausts him because he has to sit up all the night, but does not otherwise affect him. It is only because he feels detached both emotionally and physically from his mother, as he put her in a home where she lived out her remaining days. This prevents him to invoke a strong feeling of emotional attachment with his mother. When she passes away, nothing truly changes in his life. While looking at the people's fake emotions to draw the attention of others at his mother's funeral, he wonders if all the attendance actually cared for his mother or are simply going along with the necessary actions placed upon them by the society. He does not even shed a tear because he does not feel like crying. Even he chooses not to have a last glimpse of his mother when the keeper asks him to unscrew the casket to give one last gaze at her. At the vigil, he feels sleepy, dozes off for a while, drinks white coffee, smokes a cigarette and on the top of that, the following day goes to the beach, meets a woman named Marie Cordona, swims with her, goes to a comic cinema, and finally jumps to bed with her.

Meursault is not mechanically grief-stricken as any conformists might have been. That is why he wants to fulfil his bodily impulses. All men and women have these dangerous unnamable impulses, yet they keep up a pretense to themselves, to others; their respectability, their philosophy, religion are all attempt to gloss over, to make look civilized and rational, something that is savage, unorganized and irrational. Meursault is an outsider to the society, 
because he stands for truth and says no to false sentimentality. He stands away from the social conventions that obstinately attempt to conceal its repulsive part; he stands away from the artificial collective norms that prefer to live by appearance, not by experience. Meursault lives in his own private world and feels that what he has seen is truth and thus he remains committed to his belief. He is very particular about his own physical impulses, lives in the present, and gives paramount importance to the psychological consciousness of his existence over collective norms. He is essentially a pragmatist who has a matter-of-fact approach towards life and is not easily driven by emotions. This is much evident when while taking leave for his mother's funeral, he says to his employer, "Sorry, sir, but it's not my fault, you know." (p. 4); while having his mug of café au lait; when he says "I wanted a cigarette. But I wasn't sure if I should smoke, under the circumstances- in Mother's presence. I thought it over; really, it didn't seem to matter, so I offered the keeper a cigarette, and we both smoked." (p. 7); when he gets more concerned about the ache in his legs that grows to be a sort of cramp rather than his mother's body that is lying right before him; when looking at the advent of a fine day, he ponders, "I caught myself thinking what an agreeable walk I might have had, if it hadn't been for Mother" (p. 9); when he pictures himself "going straight to bed and sleeping twelve hours at a stretch" (p. 13) on his arrival at Algiers. What one can notice is that Meursault lives more of a 'sensate-life' than a 'sentiment-life'. He is not a philosopher or theologian or a thinker. He does not feign to be shaken or traumatized by his mother's demise, rather is more worried about winding up the funeral ceremony so that he gets some rest. He exists as he is, not trying to be anything more than himself.

People like Meursault undoubtedly make others feel awkward for the reason that they overtly break the social norms and live lives based on their impulse. They are peculiar creatures who strongly oppose the artificiality of outer shell that demands appearance at the cost of genuineness. Meursault expresses his indifference toward his love for Marie when she asks him if he loves her. He admits, “... that sort of question had no meaning, really; but I supposed I didn't." (p. 24) Even though Marie couldn't accept his apathetic attitude towards her love, she appreciates his blunt honesty which is the trademark of his peculiarity.

Further, Meursault is seen refusing to put a mark of hypocrisy, to pretend, to compromise. After he kills a man 'the Arab' for no apparent reason, he is put on a trial. However, the focus of his murder trial quickly shifts away from the murder itself to his attitudes and beliefs. His atheism and lack of outward grief at his mother's funeral represents a serious challenge to the morals of the society. Before his trial, the examining magistrate asks him whether he regrets the murder. His reply is that it is more of an annoyance than regret. Further, he senses the detestation of the people attending the court and his reply sealed his fate. He says, 'After thinking a bit, I said that what I felt was less regret than a kind of vexation I couldn't find a better word for it.' (p. 44). This shows his lack of concern for the victim, and eventually condemns him. Knowing this, the legal system would have taken his lack of regret into account and considered him a "heartless monster". The Prosecutor, while unfolding the background of the crime, talks about what he believes as "the most squalid description" of Meursault's personality as a prisoner is "an inhuman monster wholly without a moral sense" (p. 60). The society fails to understand his peculiarity and therefore consider him 'an Outsider'.

Finally, we see Meursault is executed, not for committing a murder; rather he is hated and given death penalty for not expressing deep emotion when his mother dies. The society is so attracted to maintain the Christian conventional behaviour that the prosecution focuses on his 
indifference; rather than the crime he has committed. The society is completely unwilling to accept this non-conformity to social protocol, unable to accept his lack of faith in his existence of a supernatural being. It is the misinterpretation of his character that leads to the wrong judgment of the society.

Meursault comes to term with the absurdity of life and nothingness of death, and prepares to welcome both equally and courageously. Camus uses the moral fiber of Meursault to shake us out of our gratification so that we can open our eyes to the vainness of lives that we live. He proclaims that we as a society do not deserve the actual Christ. To him, Meursault seems to be a more fitting character that the contemporary society ought to have. He is an individual with not only the power to accept himself as he is, by denying to act as a puppet in the game of façade and falsehood, but also the power to accept death with tranquility like Christ and Socrates. Hypocrisy is foreign to him. He refuses to lie before the judge, does not manipulate his perception towards love, marriage, creed, truth, and death whenever he is interrogated about the same throughout his trial. He never hides a truth and rather tries to remain committed to his true self. The consistency of honesty and bluntness with which he faces all the curve balls that life throws at him, makes him truly idealized in a way that majority of the society would not be able to empathize with. His apathy with respect to the societal conventions creates a fear of being influenced in the minds of many, which condemns him long before he pulls out the trigger of the gun to shot the Arab.

Camus seems to have possessed a sense of the consecrated and a power to differentiate between appearance and experience. He seems to have dismayed with the world getting colonized with people doing massacres in the name of nebulous value systems. It's not that Camus is trying to play with the emotions of his readers; it's that he is trying to trace out the idiosyncrasies of an individual who denies walking on the beaten path and remains an existential champion of honesty and veracity.

Driven by his morals, Camus idealizes his character for that he believes that there can be different ways to lead life and to deal with feelings. One who is more prone to address his bodily needs and overtly displays the same, does not necessarily end up considered as inhuman. The point he wants to hammer on is that we cannot ignore the intractable absolute reverence for truth, the brutal honesty of the individual, who in this duplicitous world, would have displayed hypocrisy otherwise. The principal characteristics of Meursault "appears to be a kind of total sincerity which disconcerts us because it is virtually unknown in our world" (Bespaloff, 1962). This view, later, gets challenged not only by scope, but also by its essence.

Camus states emphatically that Meursault is the only true type of Christ figure that we must deserve. However, he does not refigure Christ in every way because of his human fallings. He is similar to Christ as far as his honesty and truthfulness are concerned. Now the question arises- Does anyone who has this honesty becomes a Christ figure? The answer is 'No'. It requires great integrity and complete dedication to remain committed to one's 'belief'. Thus, one who has the courage to sacrifice his/her life for the sake of truth can be considered as a Christ figure.

Both Christ and Meursault were martyred because society considered them as dangerous characters and both accepted to die for truth. Both abundantly embraced life and courageously accepted death, by surrendering their mortal lives. Both were the victims of judicial errors and were in their early thirties when executed. Both had a sensitive and tough love life- Marie in case of Meursault and Marry Magdalene in case of Christ (Brown, 2016). One cannot deny the fact that, Christ, despite being rendered as the supreme spirit, is a man 
of human frailty, which is synonymous to human existence. Thus, Camus is evidently giving Meursault a Jesus persona, who himself longed his entire life in the quest for divine in human beings (Cruickshank, 1967). Camus's literature certainly combines "humanism" and "a strongly religious temperament”. Patrick Henry notes:

Both Christ and Meursault epitomize the scapegoat issue, for neither of them is killed for content, but for form, the maintenance of the form or structure upon which society is fabricated. Neither attempts to save his life, for each knows that, by doing so, he would lose the validity of that life, its authenticity and its redeeming quality that are only sustained if they are maintained to the end. (p. 162)

Now one may question if Camus's Meursault is a Christ-like figure in The Outsider, how come Meursault writes a deceitful letter on behalf of his neighbor Raymond to his Arab Exmistress with an invitation to have sexual intercourse with her and to beat her up. This certainly interrogates Meursault's 'truthfulness' and 'Christ-like' traits. The answer is intact in the scene itself where Meursault is found to have dinner with Raymond just to avoid cooking on his own. According to the New Testament, when Christ fasts incessantly for long forty days and nights, he feels hungry at the end of it. Satan finds him in an inhospitable region and suggests him to turn the stones into breads. Christ, with rage denies his suggestion by saying that Man should not only live by bread but also by the sermons of God. Following that, Satan escorts Christ to a Sierra to give him a panoramic view of the world and ensures Christ's control over the entire world on his (Satan's) veneration. Christ in response, asks him indignantly to get behind him. Finally, Satan takes Christ to the temple of Jerusalem and provokes him to exhibit his supremacy by jumping off. Christ drives him away by retorting him to not to tempt him and wins the battle of temptation. But Meursault could not. He succumbs to the temptation of Raymond, drinks alcohol, and writes the letter. Unlike Christ, who prefers not to drink in "The Last Supper", a 'not-Christ', but a 'Christ-like-figure', Meursault, with all his essentially human frailties, accepts to consume alcohol on his illomened dinner or his 'Last Supper' with Raymond, that later brings on his tribulations. He can, therefore, be portrayed as a human-Christ, with typical human frailties, who never denies any of his deeds- virtuous or abysmal. Camus in the preface to L'Etranger writes this is "the story of a man. Without any heroics, agrees to die for truth". ("Preface" 336)

Camus's view of the world is that society has certain norms and it persecutes the one who does not fit into it or deviates from it. One, who does not follow the framework, goes against the grain. Both Meursault and Christ are apostates who make their contemporary societies feel threatened. Jesus has power that is not understood by the then society, which leads to his crucifixion. Meursault "openly flouts convention and live instinctively" (Meher, 1998), which scares his immediate society; the society anticipates an unpalatable future with his presence; considers him an 'Outsider'; thereafter he is executed. Meursault, like Christ, is more of an utter victim of the societal concordats than his actual crime. Christ, 'the son of the divine' sacrifices his life for 'the sin of man'. The real reason behind his crucifixion is obliterated. Similarly, Meursault is not exactly put to trial for the murder he commits, but for the indifferent attitude he displays on his mother's funeral. His position in the novel in many ways exemplifies the role played by Christ in the New Testament. Both refuse to lie, to dissimulate in any way, to compromise with their true selves. When the penultimate moment comes, and both are asked by their Jury to say something on their behalf, both turn down the opportunity. Governor Pontinus Pilate puts the question to Jesus, trying to get him to say 
anything and save himself. Though it all, Jesus keeps his mouth shut and ensures his crucifixion. His eloquent silence at the end talks more about his desire for truth than anything else he could say. The court scene of Meursault induces various aspects of the last judgment of Christ as Meursault does not utter a single word on his behalf, to defend his trial when the judge asks if he has anything to say. Faced with the guillotine at the end of a sham trial, he could have railed for the system or begged forgiveness. Instead, he chooses to say nothing. Saying anything at that point would have been banal; there was nothing relevant he could say. Nothing would change the society as for the society he was misunderstood, held responsible for being some kind of hardhearted ogre, and executed for the 'indifference' he displayed to the society, when in fact, they were both merely the implication of his 'honesty' to a "profound and tenacious passion for the absolute and for the truth". Thus, he should not compromise his personal integrity for that. He believes that pure existence is the only truth. His integrity to truth and honesty is untainted. He believes that all the conventional human values are pure deceptive and remains committed to his belief till his last breath. With correspondence to his purpose, his persona and his providence to that of Christ, Camus's character is no less a 'Christ-like figure'.

\section{Conclusion}

Ours is a cynical age. Our society believes in walking on the beaten track. There is a tendency to believe that things never change, the inertia of daily existence, is a staple of living. Any deviant is treated with contempt. Christ disturbed the society with his 'radical ideas'; Meursault disturbed the conventional rules of the society with his 'radical living'. Thus, if Meursault is a Christ like figure, he is the one that our age deserves.

\section{References}

Bespaloff, Rachel, (1962). Camus: edited by Germaine Bre'e., U.S.A: Englewood Cliffs: N.J. Prentice-Hall. p.93.

Brown, Dan, (2016). The Da Vinci Code. New York: Delacorte Press.

Camus, Albert, (1942). The Stranger. Trans. Stuart Gilbert. New York: Vintage Books.

Camus, Albert, (1955). Preface to L'Etranger. ed. Germaine Bree. New York: AppletonCentury-Crofts. p.336.

Camus, Albert, (2001). Bloom's Modern Critical Interpretations: The Stranger. Ed. Harold Bloom. New York: Infobase.

Cruickshank, John, (1967). "Albert Camus: Sainthood Without God". Mansions of the Spirit: Essays in Literature and Religion. Ed. George A. Panichas. New York: Hawthorn.

Henry. Patrick, (1975). "Voltaire and Camus: The Limits of Reason and Awareness of Absurdity". Studies on Voltaire and the Eighteenth Century. Voltaire Foundation. (138): 162.

Maher, Eamon, (1998). "Camus' Meursault: The Only Christ That Modern Civilisation Deserves?”. Studies: An Irish Quarterly Review, 87 (347): 276-281. 